\title{
“IT'S ALWAYS A MEANS TO AN END”: QUEERING THE CARIBBEAN LITERARY SPACE IN VALMIKI'S DAUGHTER
}

\author{
Leila Assumpção Harris* \\ Universidade do Estado do Rio de Janeiro \\ Rio de Janeiro, RJ, BR \\ Raquel Gonçalves Pires \\ Universidade do Estado do Rio de Janeiro \\ Rio de Janeiro, RJ, BR
}

\begin{abstract}
The legacy of a colonial past marked by violence and oppression still influences sexual politics on the Caribbean Islands. The absence of laws to protect LGBT citizens together with firmly rooted heteronormative structures make the islands an inhospitable place for those who do not comply with the rules, reinforcing the idea of Caribbean LGBTs as virtually inexistent. In Valmiki's Daughter Shani Mootoo uses literary representation to break "the silence about sexuality and nonnormalizing desire". The novel underscores the sexual diversity of individuals situated inside a region that has been perceived as primarily heterosexual, a perception that needs to be deconstructed. However, Mootoo implicitly acknowledges the constricted space for individuals that do not abide by compulsory heterosexuality, attesting the power of discursive processes and practices that still regulate bodies, genders and desires.
\end{abstract}

Key words: Caribbean literature; heteronormative rules, body, gender; discourse.

To deal with sex, power employs nothing more than a law of prohibition. Its objective: that sex renounce itself. Its instrument: the threat of a punishment that is nothing other than the suppression of sex. Renounce yourself or suffer the penalty of being suppressed; do not appear if you do not want to disappear. Your existence will be maintained only at the cost of your nullification. Michel Foucault, The History of Sexuality.

The body implies mortality, vulnerability, agency: the skin and the flesh expose us to the gaze of others but also to touch and to violence. [...] although we struggle for rights over our own bodies, the very bodies for which we struggle are not quite ever our own; the body has its invariably public dimension; constituted as a social phenomenon in the public sphere, my body is and is not mine. Judith Butler, Undoing Gender

The Caribbean islands are known as a getaway place for tourists searching for exotic scenery, a relaxed atmosphere, and even easy access to sexual pleasure. Sex tourism is one of the biggest industries in the region and unauthorized agencies carry "advertisements in European magazines announcing 'package deals' including the service of a local male or female" (Gibbings 1997). ${ }^{1}$ The recent movie feature Dolares de Arena (2014), directed by Laura Amelia Guzmán and Israel Cárdenas and set in the Dominican Republic, foregrounds the complex

\footnotetext{
* Leila Assumpção Harris is an Associate Professor at Universidade do Rio de Janeiro. At present, she is the coordinator of the Master's course in the literatures of the English Language. Her main research interests include autobiographical writing, gender and cultural studies. Thanks to a state-sponsored grant (Prociencia/ FABERJ), she is currently researching autodiegetic narratives produced by contemporary women writers.

${ }^{*}$ Raquel Gonçalves Pires currently teaches English as a second language. She holds a Master's Degree from UERJ. Her dissertation, Compulsory Heterosexuality and Caribbean Queer Identities: An investigation of Achy Obejas's Memory Mambo and Shani Mootoo's Valmiki's Daughter (2015) as well as book chapters published to date attest her interest in gender and queer studies.
} 
relationship between an older French woman and a young Dominican girl. The movie treats same-sex relationships without any judgment and the directors focus on the complex, affective bonds between the women. In a context that ostensibly naturalizes social inequalities and exploitative practices, the human body is a valuable commodity and the exchange of sex for money is faced naturally, albeit for very different reasons, both by the locals and by the tourists.

Yet the image of the Caribbean islands as a hedonistic space where heteronormative rules are not enforced is misleading, applying mostly to those involved in sex tourism. LGBT individuals living on the islands often lead covert lives to protect themselves from threatening situations. Non-compliance with heteronormative rules is complicated even in countries where violence against LGBT is forbidden by law; in places that offer no legal protection whatsoever, and even criminalize homosexuality, the situation becomes even more delicate.

Writing from a legal standpoint, Toni Holness carefully evaluates the situation of LGBT citizens on the islands and argues that many of the obstacles to the creation of protective laws stem from the fact that "the Caribbean's apprehension to Lesbian, Gay, Bisexual, Trans, and Intersex rights advocacy is deeply rooted in the region's tragically oppressive colonial experience" (926). Thus, Caribbean countries oppose the creation of human rights laws in order to sustain a recently acquired autonomy from their previous colonizers, as if the creation of such laws would somehow imply a continued dependence on colonial policies. Obviously, preserving their autonomy is not the only reason why Caribbean countries do not criminalize homophobia. ${ }^{2}$ The idea that homosexuality itself is a product of a white (as American/European) society is also a stumbling block, since acknowledging the existence of LGBT citizens would involve accepting one more aspect of the culture that has for so long oppressed the islands.

Literary critic Alison Donnell, who agrees that on the islands homosexuality is considered "a European export or contamination” (Donnell 2006, 201), offers yet another explanation for the local strength of heteronormativity: "Caribbean heterosexual identities are rooted in constructions of reproductive sexuality bequeathed by slavery and deployed post-emancipation by both men and women as a way of claiming social entitlements." (201) Thus, the urge to be seen as good procreators reinforced heterosexuality and became yet another legacy of the slavery system and the colonial rule. ${ }^{3}$ Ironically, many Caribbean nations fail to acknowledge that their own anti-sodomy laws and prejudice against homosexuality have their origins in Section 377 of the British Code which dictated that any form of sodomy was prohibited, and that punishment could be as severe as the death penalty (Holness 942).

The imposition brought by language is an additional obstacle to the discussion and acceptance of LGBT issues. Terms such as "queer", "gay", "lesbian", and "homosexual" were coined inside an imperial framework that neither classifies nor represents the diversity of sexual identities located inside the islands. For this reason, "Caribbean writers do not adopt the terminology of the West in order to name this experience or desire. Their writings are rather characterized by an un-naming of this desire and sexual practice" (Donnell Caribbean Literature 184)

The absence of protective laws together with heteronormative structures make fiction and nonfiction works, written by Caribbean authors that deal with divergent sexualities of individuals within the geographical region of the islands, difficult to come by. ${ }^{4}$ With Our Caribbean: A Gathering of Lesbian and Gay Writing from the Antilles (2008), editor Thomas Glave took a necessary step towards gathering fiction and non-fiction works featuring LGBT issues, written by Caribbean authors living on the islands or abroad. Publishing the collection was difficult since multiple editors and agents believed the book would be too "narrow", focusing on "a slice of a slice", reinforcing once more the idea of Caribbean LGBTs as virtually inexistent (3).

Shani Mootoo, one of the authors included in Glave's collection, has published novels, shortstories and poems that have contributed to breaking "Caribbean literary silence around sexuality and nonnormalizing desire" (Donnell "Caribbean Queer", 214), thus queering the Caribbbean literary space. 
Born in Ireland from Indo-Trinidadian parents, she lived in Trinidad from the time she was three months old until the age of nineteen, when she moved to Canada to pursue her college education. ${ }^{5}$ Sissy Helff and Sanghamitra Dalal argue that "many of Mootoo's protagonists struggle with the strictly normative order set by the closely knit Indo-Caribbean society since the space dedicated here to homosexual and bisexual people is rather limited" (78). In Valmikis Daughter, Mootoo dramatizes some of the consequences of imposed gender binaries upon the characters, including their need to live double lives in order to conform to heteronormative practices and appearances. She also addresses identity issues affecting Indo-Trinidadians both inside and outside their country, including the previously discussed silencing and discrimination towards LGBT citizens in the Caribbean.

Unlike her first two novels, Cereus Blooms at Night and He Drown She at Sea, both located in fictional islands on the Caribbean, Valmikis Daughter is set in the very real city of San Fernando. While guiding the readers through its streets, Mootoo asks them to imagine themselves as "tourist[s] let down from the sky" and describes how their senses would be "bombarded at once" (7) by the different sounds and smells of the island. Together with the geographical description of Trinidad's largest town, Mootoo introduces the reader to different people and structures (social, racial, and geographical) of the region. Thus, this detailed description of the setting serves a further purpose beyond engaging the readers in the story. While conveying a sense of ordinariness, Mootoo manages to disclose the cultural richness of the country, the distinctions between next-door neighbors along with diverse (though covert) sexualities. Donnel suggests that

[i]t is no coincidence that our initial orientation as a reader is to Trinidadian streets that refuse a straight journey and lead, rather, to a maze of entangled routes, for this too is the human landscape of the novel once we venture beyond the façades of its seemingly socially wellcoordinated lives. ("Caribbean Queer", 215)

This strategy enables Mootoo to evoke a sense of normalcy, while simultaneously showing that, "beyond the façade" anything and everything that happens is not uncommon, though it might go unnoticed most of time. As Donnel underscores,

\begin{abstract}
In the face of repeated assumptions of impossibility around nonheteronormative lives, Mootoo's novel catches a Caribbean queerness that maps a new meeting point between place and the possible. By rendering the commonplace sexual pluralism of Trinidad that blends 'straight' and 'gay' among other queer realities, Valmiki's Daughter gives representation to a locally sensitive yet socially subversive repertoire of attachments and desires that exceed identitarian categories and binaries. ("Caribbean Queer", 214)
\end{abstract}

The novel chronicles the lives of two Indo-Caribbean families, the Krishnu and the Prakash, focusing primarily on the former. Patriarch Valmiki Krishnu, his wife Devika and their two daughters Viveka and Vashti are apparently a common upper-middle class family of Hindu origin, and play an important social role in their community. However, things may not be as simple as they seem, for Dr. Valmiki Krishnu is actually a closeted homosexual who engages in casual yet frequent intercourse with women in order to flaunt his masculinity while hiding his desire towards men. His wife is aware of his affairs as well as of his homosexual inclinations, though she chooses to ignore any deviation in his conduct. While the younger daughter Vashti fully conforms to the social and familial norms, Viveka, the older one, is a rebellious college student in search of her own experiences.

Upon returning from Canada, newly-married Nayan Prakash presents his French wife, Anick, to the Trinidadian society and to the Krishnu family. Though belonging to the upper middle class in Trinidad, in Canada Nayan had struggled in order to maintain his status, since his skin color dictated how he was perceived by others. His marriage to a beautiful white woman, apparently motivated by genuine interest, serves as a way to uphold his social status, both in Canada and in Trinidad. ${ }^{6}$ However, upon arriving on the island, Anick feels lonely and isolated, and develops a close relationship with Viveka Krishnu, destabilizing the couple's lives and Viveka's sexual identity. 
Yet, perhaps one of the most important characters of the novel does not belong to either family. Merle Bedi is Viveka's former high school friend, but she is introduced in the narrative by Vashti, who runs across her unexpectedly.

[Merle] appears to be old and haggard, but Vashti knows she is only a handful of years older than she is. The woman is, in fact, the exact age of Viveka, Vashti's sister. The woman is thin, with the depleted meagreness of the alcoholic. Her long black hair is oily and clumped. She wears what was once a white shirt, a school shirt from not too long ago, but it is yellowed and soiled, and the trousers she wears, men's trousers, are covered in dirt, dust, urine. They are several sizes too big for her, held high above her waist with a belt and, as if that were not enough, a length of heavy rope. She is barefoot. (22)

In the path-breaking article "Compulsory Heterosexuality and Lesbian Existence" (1973), Adrienne Rich discusses the many ways in which "heterosexuality has been both forcibly and subliminally imposed on women. Yet everywhere women have resisted it, often at the cost of physical torture, imprisonment, psycho surgery, social ostracism, and extreme poverty" (138). In Valmikis Daughter, Merle Bedi is a literary representation of one such woman. She becomes homeless and needs to turn into a prostitute in order to survive because, once she decided to disclose her sexual preferences, she was promptly cast away from her family and society. Forced to live on the streets, with no family or home to go back to, Merle Bedi looks for a friendly face that could help her and maybe "spare some money". Though Merle had previously been a part of the same social circle as Vashti, the only concern in the latter's mind is not to be seen talking to a woman who uses her body for money. Yet, Vashti ponders to herself that being a prostitute is not the worst, since

[...] if she is doing this sort of thing, what they say about her can't be true then. It can't be so that she is a buller. If is woman she like, how come she doing it with man? Well, maybe is not a bad thing, then. That might cure her. And from such a family, too. It is killing her parents. No wonder they put she out the house. (23)
Vashti's thoughts reflect the general opinion of Trinidadian society that homosexuality is a form of behavior, perhaps a disease, that can be corrected or cured if the individual engages in a heterosexual relationship. It is an action that needs to be disciplined, even if that discipline is achieved through the also frowned upon practice of prostitution, which although condemned by society, is considered less harmful than homosexuality. In the novel, Trinidadian society, or at least the part of society Vashti and her family belong to, think that heterosexuality is the normal path for women, completely erasing the possibility of their having feelings that differ from the heteronormative rule. Merle Bedi defies that rule and is sentenced to a life on the streets. Discrimination inside the family, therefore, is the very reason why she is without a family in the first place. Her family members, along with Trinidadian society, seem to prefer what Rich termed "the lie" of compulsory heterosexuality that "keeps numberless women psychologically trapped, trying to fit mind, spirit, and sexuality into a prescribed script because they cannot look beyond the parameters of the acceptable" (140).

This need "to fit mind, spirit, and sexuality into a prescribed script" is imperative to Viveka, Merle's former friend and Valmiki's older daughter. Because of the consequences endured by her friend, she feels the constant need to check herself and to avoid transgressing norms society has drawn for women. Inside her house these norms are enforced mostly through her mother Devika who yearns to control the way Viveka dresses and behaves in order to make her more "ladylike". When Viveka insists on getting her parents' permission to play volleyball in a court near her college, Devika is completely against her daughter's playing any kind of sports because, in her opinion, "Viveka already lacked a certain finesse one wanted in a girl, engaging in team sports and competition might only make her that much more ungainly. And whatever polish she, Devika, had tried so hard to impart would certainly be erased" (49). Clearly, in this instance, "polish" implies controlling the body as well as the actions of her daughter, since society considers body appearance and behavior as sure signs of one's identity. Furthermore, sports activities are seen 
as pertaining primarily to a male environment, thus improper for "ladies".

Valmikis memories of his own experiences as a young man lead him to associate sports activities with homosexual behavior, causing him to worry about Viveka.

While team sports involved various kinds of camaraderie and, yes-yes, all that important exercise, it had the potential to involve something else: complicated kinds of physical contact. He knew something of this; he had played soccer with boys from his high school and, later, soccer and cricket at university. And even as he sensed the foolishness and futility of trying to protect her, he couldn't bear to give his daughter, this one in particular, permission to enter an arena that could stir within her, like it had in him, a confusion she would absolutely have to keep to herself. He wasn't entirely sure that this would happen, but it nagged at him that it could. (50)

What the parents cannot see is that playing a sport is not what would change Viveka. Like Merle, she too was attracted to a teacher, Miss Sally Russell, but Merle's fate acts as a constant reminder to Viveka of the life she is bound to have if she ever talks about her own feelings or inclinations. Viveka is haunted by her former friend even after she becomes involved with Anick Prakash. Because of a society's script that does not allow homosexual behavior and because of the consequences she has seen in Merle's life, Viveka avoids displaying any attitude that would lead others to suspect that she has a relationship with another woman.

In one of their first meetings, after having already developed an interest in Viveka, Anick confesses that she is just like many other French girls, and that she likes both (women and men). However, Viveka cannot bear to let her feelings come to surface. As time goes by

Viveka oscillated between two poles. She decided one minute to still whatever thoughts and feelings Anick Prakash had stirred in her. Such thoughts and feelings were dangerous tricksters out to trip her up and land her, like Merle, out on her own, family-less. And Anick Prakash, being the root of such thought, was even more dangerous. (261)
Again, the influence of Merle is important in dictating how Viveka decides to lead her life. Even though she feels like a stranger in her own house, she does not want to risk losing her family or bringing dishonor upon them. Viveka's "sense of loyalty or responsibility towards her family and to the society at large" (Helff and Dalal, 80) is the driving force that keeps her afraid of breaking the silence about her sexuality. She realizes that in Anick's arms she was able to feel whole for the first time. However,

with this ephemeral knowledge came another thought: the dreadful possibility of losing her family. Which was greater, she wondered to be all that you were, to be true to yourself, or to honour one's family, one's society, one's country? Her family, despite everything, was her life. She could never be without them. She could never do to them what Merle Bedi had done to her family. She wondered if her family could do to her what Merle Bedi's family had done to Merle. Again she felt an urge to go and find Merle, to talk to her. Take her away. But away to where? (326)

In the quote above, and in several other instances, Viveka expresses an intention to flee Trinidad, believing that she cannot be herself there. Nevertheless, even though the idea of homosexuality as something problematic is much stronger within the IndoTrinidadian enclave, such prejudice is not limited to that particular group or country. After Viveka's insistently questions her French lover why she married a man, Anick remarks that

Everybody think the French, they so enlightened. They think French and enlightenment go together. But that is so simple, no? The French, especially outside of the city, they like everybody else. My parents, they are the same. French does not equal enlightenment, Vik. It does not mean freedom. Get that into your head. It would be easier for my parents if I marry a man from Morocco, Algeria, or from Senegal or Trinidad, than if I choose to live with a woman. (346) 
Prejudice towards sexual minorities is a reality not only in places like the Caribbean but also in developed countries like France. Albeit in a lessened degree, the fear of non-acceptance that Anick feels is similar to Viveka's. As Anitta Mannur reminds us, the West is not necessarily "the liberatory space that allows for a freer celebration of non-heteronormative sexualities" (286). Yet, if the West still establishes politics of compulsory heterosexuality, countries where the consequences of colonialism are still felt may impose it even more severely.

Judith Butler's questioning the general belief that "one is one's gender to the extent that one is not the other gender" (Gender Trouble, 30) is instrumental to our understanding of Mootoo's protagonist. Viveka repeatedly states that she feels inside her the presence of her younger brother, who passed away as a child. "She certainly often felt as if she knew what it would be like to be him, and as if she knew, too, the kinds of women he would be drawn to. He would be drawn to Anick" (286). Yet, for Viveka, fitting in one category of gender is not possible because there are traits associated with femininity and masculinity within her, and together they form who she really is. The first time she makes love to Anick, Viveka admits that both women and men are present within her, by saying that "during the initial moments of their lovemaking, [she felt] a sense of having taken on the form of a young man's body. Her body had become, albeit briefly, Vince's body, and in other moments Anand's" (322). Vince is the code name for invincible, the blond haired boy that Viveka imagined lived inside her when she was younger.

Even though she imagines herself as a man, she realizes that "she knew now more than ever that her feelings and her way with Anick were hers and hers alone. Not a boy's. Not a man's. Whatever she was, these feelings were hers" (323). In this moment, masculinity and femininity become, through Viveka, two halves composing her true gender identity, and choosing to act more "feminine" or more "masculine" will be a performance that will depend on the situation in which she is placed. Butler mentions that "if the inner truth of gender is a fabrication and if a true gender is a fantasy instituted and inscribed on the surface of bodies, then it seems that genders can be neither true nor false, but are only produced as the truth effects of a discourse of primary and stable identity" (Gender Trouble, 186). In the novel, since Viveka does not abide by the gender fantasy, she feels that both masculinity and femininity belong to her. As Viveka mentions, there's still a sense of evolving. Viveka's evolution, if it is possible to call it that, reaches its highest point when she and Anick make love for the first time. Viveka then realizes that "perhaps she could be finished with Anand now. And with Vince" (323).

Sexual initiation as a rite of passage works positively for Viveka, who stops being a teenager and turns into a full woman. Instead of asking again for permission to play on the volleyball team, she simply decides to join it. Instead of asking her parents to change her appearance, she just has her hair cut short. Even her mother, though not surprised by the fact, is shocked by the way she changed so fast and "now Devika, too, saw the ghost of Anand in their daughter" (340).Though she may still look like her younger brother, she feels like the woman she is, now more confident and self-assured of what she wants to go through. But society's chains still hold a strong grip over her and she feels the need to go elsewhere to find freedom. After Anick becomes pregnant and their relationship ends, Viveka decides to try going out with Trevor, a man who has been courting her for a while.

Viveka realizes he may be a way out of the place she wants so much to flee. He is also the only person that is comfortable talking about Viveka's relationship with Anick. He is the only one that notices the women's small touches on the volleyball court, and asks unashamedly about Viveka's relations with the woman. Although reluctant at first, she ends up confessing that they really had a romantic affair. Viveka and Trevor, then, decide to marry. She, in order to go somewhere else and experience with her new sexual awareness, he, for reasons not clearly expressed in the novel, but that do not seem so different from Viveka's, for he too displays non-conforming behavior regarding sexuality. His marriage proposal does not come from a heartfelt wish to marry; he comments instead that "it's always a means to an end" (376). ${ }^{8}$ That confuses Viveka, who realizes how true his words were, at least for her. Furthermore, 
Trevor does not explain why he chooses to marry an Indo-Trinidadian woman before returning to Canada and he does not display any sexual desire towards Viveka, even when she, much to her own surprise, feels desire towards him. The novel ends with a conversation between Trevor and Viveka

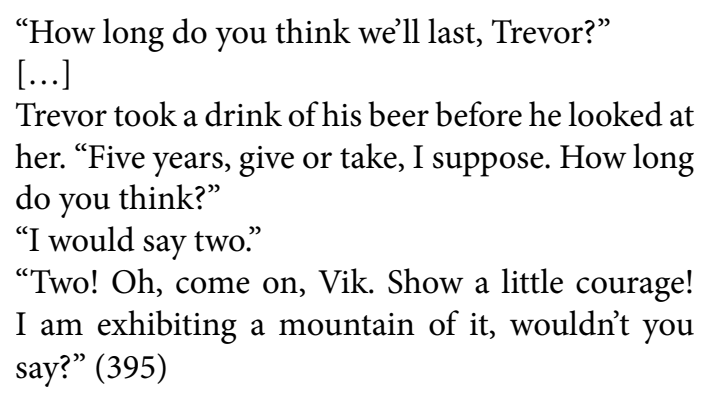

Not only is the dialogue strange coming from two people recently engaged and about to get married, but Trevor's "courage" leaves little to no doubt that his intentions in marrying also come from a need to conform, as a way to escape from previously set society norms, much like it is for Viveka.

It would seem then a return to the old ways, in which women (and, in this case, a man) would have to get married in order to prove their normalcy to the world around them. However, in Valmikis Daughter, this marriage is not seen as a forced act. Instead, it is Viveka's choice, and hers alone, to become engaged to Trevor and embark with him on a journey to Canada. Shani Mootoo mentions in an interview to STAN Magazine that "in fact, the marriage is an escape for [Viveka]. Not an escape into that marriage, but marriage is an escape out of her situation to another thing from which she can get out of the marriage itself" (Rampaul 25). Therefore, though it may not seem so, Viveka is actually using marriage as a way to achieve the freedom she has wished for so long.

Nonetheless, even if it is not the case with Viveka, marriage does act as a way to conform and "perform" normalcy for some individuals. While the young woman sees marriage as a geographical escape from the island, and as a way to finally be able to express her true sexual identity, young Valmiki, Viveka's father, wished to escape from the lifestyle he had while studying abroad but could not pursue once he returned to Trinidad. His marriage then can be configured as a reverse escape. That is, in order to be free from society's stigmatization he chose to marry Devika, therefore, putting his own life into imprisonment, since from that moment on, he would not be able to express himself, at least publicly. His marriage to Devika was carried out because of expectations of a society that sees heteronormativity as the only road to take. Valmiki uses his marriage as a shield, one that protects him from prying eyes, and renders him able to perform his "deviant" sexual activities in hiding.

At different moments, the narrator makes clear that Valmiki lives a double life. Right from the start, it is possible to interpret Valmiki as a nostalgic man, still trapped in the events that took place in a distant past. Those events involve his marriage, a homosexual relationship he had had when in college, and also an incident that goes further back to a time when Valmiki was still a child and had his first sexual experimentations. It is necessary to understand the background in which to place the sources of those nostalgic feelings, which involve personal reasons as well as social pressures.

In a society such as the Trinidadian, though not restricted to it, there is a high expectation of how a "real man" should behave. Linden Lewis points out that "to deviate from notions of how real men are supposed to act and what real men are supposed to represent often leads to feminization-hence the tendency to conform to ideals of normative masculinity" (6). In other words, not acting according to the expectations of society concerning masculinity may be interpreted as a sign of femininity, especially considering the constraints of the binary gender system.

Focusing on different novels written by Caribbean writers, Geraldine Skeete discusses the pressures placed upon young gay characters "to adhere to a compulsory masculinity in preparation for manhood [and] face emotional, psychological and public pressure to conform to male, heterosexual standards". She believes this pressure leads to "performances of hypermasculinity, compulsory masculinity and heterosexuality" (11). Although Valmiki's Daughter is not part of her discussion, it is not difficult to see that Valmiki fits this pattern. Marriage was the first step Valmiki took towards conforming to heterosexuality. 
Even though he had lived an intense relationship with the young tutor Tony when still a college student in Scotland, the patriarch of the Krishnu family "had known that upon qualifying he would return home-to Trinidad, that is-and marry. He had known that was what he had to do" (66). The only option left for him was to conform to a heteronormative lifestyle his family and society systematically imposed. Valmiki, then, "fully accepts the limitations and restrictions placed upon him by the social expectations of acting like a "true man" and the family patriarch" (Helff; Dalal 79).

Valmiki's wife, Devika, acknowledges her husband's need to prove himself around the house by doing common male activities. Even though the family could easily afford paying a worker to fix small things around the house, Valmiki is the one who insists on performing the jobs. Though others may have doubt as to the reason he chooses to do so, Devika knows that "he wanted to be the man about the house for his daughters" (128). However, this extremely constricting life of having to prove himself did not lead to happiness, and Valmiki found a way to breakout, if only sporadically, from the pressures placed upon him. This escape was found in Saul, an African-American low-class worker with whom Valmiki developed a relationship.

Saul had been one of Valmiki's patients, and the doctor became fond of him rather quickly. According to Valmiki "Saul would look directly at [him] with those eyes as if he could see through Valmiki. He was not like other men, not afraid of long, insistent eye contact" (56). Upon receiving an invitation from the patient, Valmiki decides to join him and his friends in hunting. From this moment, hunting becomes an activity Valmiki thoroughly enjoys for varied reasons. First, the sport becomes a means through which Valmiki is able to enjoy male company and feel a sense of belonging that had not been previously experienced:

Such camaraderie made Valmiki bristle with life in a way that not even the practice of surgery had ever done for him. In the forest with the men he might have been duty bound, but he was not weighed down by it. He was no one's father, husband, employer, or healer. He was one with them. They were one with each other. (57)
Secondly, beyond relieving him from the pressures of family and society, hunting is also a way to reaffirm Valmiki's male status. Since the sport requires abilities generally associated with males, such as strength, concentration, and precision, it is a further alibi Valmiki uses to hide his homosexuality, and it can be classified as the hypermasculine performance Skeete has mentioned. Beyond that, as Valmiki and Saul's relationship goes from friendly to sexual, the excuse of hunting becomes a way to meet each other without raising suspicions of their true involvement.

Yet, hunting is not the only trick Viveka's father plays in order to display hetenormativity. He also engages in frequent, not so hidden affairs with a fair number of women. His involvements were often with "foreign white women, all beautiful in the way that men commonly-or common men-liked their women" (41). By stating that the women were the ones desired by common men, the narrator may be suggesting Valmiki's own wish of being a common man himself or implying that he does not see himself as a common man.

But even more than acting like a common man, who undertakes common male activities and relationships, Valmiki's ultimate wish still remains to break free:

[...] he sometimes wished, though, that stories
of his philandering would leak-no, rather
explode-throughout the town, and cause such
a scandal that his family would toss him out
like a piece of used tissue or flush him from
their lives, and he would be forced to leave
the country. He would be freed. He revised his
thought: perhaps he, forever concerned about
appearances and doing the praiseworthy thing,
would never really be free. (42)

Although Valmiki regards breaking free as his ultimate wish, he realizes this endeavor is not possible for him. Moreover, though there remains a wish to be part of that society, he does not hold himself from judging that same society for its wrongdoings. According to him

If philandering had been for him a sword, it was the double-edged kind. On the one hand, it was a suggestion of his more-than-okay 
status with the ladies (not one, but many) and so worked against suspicions of who and what he was at heart. A man was certainly admired by men and by women for a show of his virility, even by the ones he hurt. On the other hand, since philandering had never been a shame in Trinidad-a badge it was, rather - for a man who wanted to be caught, broken, and expelled, it was a problem. (42)

Sexual freedom, therefore, is not so easy to achieve, especially when subjects are placed in constricting and oppressive environments, such as the one Valmiki belongs to. Moreover, in a heterocentric society that sees cheating and lying as acceptable behavior while perceiving homoerotic desire as a disease, there is not much space for an individual to act as his true self. However, there is an intense distortion of the meaning of loyalty, since in this context being loyal to the family does not mean being honest, but being able to maintain appearances and a good reputation in front of society. Mootoo comments on these contradictions in the interview to STAN Magazine: "they are lies-they are not white lies-they are lies that hurt wives, they are lies that hurt children" (Rampaul 22). Either way, those individuals keep lying because they still feel the need to maintain their reputation, a reputation that would immediately be ruined once those same individuals were perceived as homosexuals.

Once again, homosexuality is recognized as a reason for shame, and as a dishonorable action towards one's country and towards loved ones. In this sense, Viveka's and Valmiki's attitudes intersect once more, since both feel the weight of duty towards the ones they love. The claim of shame as a constant sharing in both their lives is also raised by Evelyn O'Callaghan who stresses the constraints placed upon the characters and keeps them from "loving as they wish" (245). When those characters are placed in a hostile background such as Trinidad, where loyalty and duty towards family is interpreted in particular manners, and homoeroticism needs to be covered, "to own the identity is to compromise one's legitimacy as Caribbean" (246).

Valmiki is not comfortable with himself, and Devika is uncomfortable with the fact her husband is gay. This discomfort is partial consequence of what being comfortable would bring, which refers back to the idea of being ashamed of who you are. Such discomfort is illustrated by the fact that neither he nor she is able to verbally express Valmiki's true identity. During a fight, Devika argues with her husband and says: "you knew what you were, you knew you were..., but is unable to finish her sentence, since verbalizing the word homosexual would make the assumption shameful. Valmiki cannot mention it to his wife either, and though he sometimes tries to say it, he cannot even admit it to himself. Actually, the word homosexual is only mentioned twice in the whole novel, once by Devika and once by Nayan. The first expresses it in a thought that she, again, cannot verbalize. When Valmiki mentions he might be willing to take a job as Health Minister, "the words that pooled in her head were: 'Wife of the homosexual Minister of Health, you mean. The words she let fly were: 'What? You're not serious?'” (129). Once again, there is an intrinsic denial of homosexuality since it is seen as shameful behavior. The words "gay" or "lesbian" do not appear even once in the novel.

Devika rationalizes that "aberrations were not to be encouraged, but very smart, busy people with heavy responsibilities should be allowed an aberration once in a while, and all that should be asked of them is that they do not flaunt it" (120). That is, the problem itself does not lie in the "aberration" her husband is committing, but in people finding out about it. Displaying it, putting it in the public eye, is what would bring people the ultimate shame of being discovered, of being recognized as "other", making them marginal to the society they belong.

Curiously, Devika and Saul's wife react differently to their husbands' homosexuality. Upon meeting Devika in a street market, Saul's wife introduces herself to her. At first, Mrs. Krishnu believes that the woman "didn't encourage or approve of the kind of man her husband was" (124), and decides to act politely. But Mrs. Saul Joseph starts a conversation that surprises and embarrasses Devika, because she touches on the very subject Devika has tried to avoid for so long: her husband's sexuality. Mrs. Joseph says: "Well, what to do? Just look at our crosses, na. You and me, we in this thing together. You know what I am talking about, eh?” (124). 
Devika agrees by nodding her head, not because she wishes to acknowledge the situation and believes them to be equal, but because denying her understanding would probably lead the other woman to attempt a further explanation that was not at all desired. Mrs. Joseph's acceptance, however, has distinct roots from Devika's silences. The fact that she endures her husband's so-called deviances is not to uphold her social status in an upper middle-class neighborhood, but to maintain the basic necessities for survival. As a way of explaining her reasons to Devika, Saul's wife states:

I know women living right on my street-my short street have two of the - who don't come out they house for days because they don't want nobody to see how they eye black or they lip bust. Me? I don't have a mark on my body. I am not starving and I have a roof over my head. I have plenty to be ashamed of and to hide but I also have much to be grateful for. Life is a blessing itself. How you managing? (125)

Yet, Mrs. Krishnu does not consider herself to be equal to a woman such as Mrs. Joseph. Although recognizing that she also has a lot to be thankful for, Devika believes that, no matter the gravity of one's burden, a public market, where others can hear, is not the ideal place to discuss such circumstances. She is aware of women from her own social circle who suffer from violence inside their homes, but feels that "this sort of thing was not something people chatted about so unabashedly, and especially in a public place such as the Mucurapo Street Market" (125). Still, Mrs. Joseph's words touch Devika, and she realizes that, though not happy, she should be thankful for what she had, even if it included her husband and daughter. A daughter that actually has the same inclinations as her husband, inclinations that Devika is also aware of, but once again, is unable to talk about openly:

There were moments, Devika admitted-to herself only-when she was relieved that Viveka didn't show herself. She made hardly any effort to make herself attractive, and after what had happened with that Bedi girl, living like a street person on the promenade, Devika worried about her own daughter. She would not form a sentence even in the recesses of her mind to say what it was, exactly, that worried her or why. The only words that come to her mind were, Wives know what their husbands won't tell them, and there isn't a thing that a mother does not already know about her child. (126)

Devika does not verbalize her thoughts, for doing so would be validating Valmiki's and Viveka's homosexuality. By keeping silent, she keeps homosexuality hidden and prevents herself and her family from suffering the shameful and uncomfortable consequences of such behavior.

Wishing to be free yet afraid to bring shame upon the family become, then, two aspects in which father and daughter share a common ground, but not the only aspects. As a matter of fact, their struggles intersect throughout the novel. And although father and daughter's relationship does look turbulent, they share a lot more than just a wish, successful or not, to escape. This connection is made even clearer when talking about the space both of them inhabit. Not a metaphorical social space, but an actual geographical space inside their society which is characterized by the forest, where Valmiki and Viveka enjoy momentary freedom and protection from shame.

This choosing of space by Mootoo was certainly not accidental. As homosexual individuals are seen as inhabiting the margins of society, their meetings need to be not only hidden, but hidden away. Therefore, engaging in homosexuality in the woods is a proof of how distinct sexual options need to be experienced further away from the eyes of society at large, and as a consequence, become even more marginalized. ${ }^{9}$

The lives of homosexual individuals, then, are restricted to two distinctive poles. On one hand, there is the forever hurting need to break free, to be one's true self. On the other, the constant fear of bringing shame to loved ones, the fear of not being recognized as a real part of one's your own family and country because of inherent same-sex desire. Both desire and fear find their solution in the secluded space of wooded areas. And though it might be the aspect in which father and daughter most show similarity, it is also where their destiny becomes opposite. It is clear that both of 
them turn their backs to the space they so long wish to inhabit, a free space to display their sexual preferences, but while Viveka turns her back and runs to another place she believes will fulfill her dreams, Valmiki, however, falls into the ultimate pressure and so-called duties society has imposed on him. He, then, goes back to the old way, and decides to interrupt any kind of relationship with Saul or any other man. Mootoo's tale is open-ended. Viveka has not reached her destiny yet, but it is clear that she is on the right path. At the same time, Valmiki realizes he will remain confined to the literal and metaphorical territory society has delineated for him. Ultimately he is as trapped and defenseless as the prey he hunted.

In Gender Trouble, Judith Butler discusses why homosexuality is still frowned upon, arguing that in order to overcome society's boundaries it is necessary to understand that it is that very same society that imposes the rules it believes should be followed. Therefore, the feeling some have that homosexuality is unnatural is not inherent inside a certain group, but constructed through intense discourse and politics that arise in that very group: "This very concept of sex-as-matter, sex-as-instrument-of-cultural-signification, however, is a discursive formation that acts as a naturalized foundation for the nature/cultural distinction and the strategies of domination that this distinction supports" (50). Working with Butler's convictions that discourses "do actually live in bodies" and that "bodies in fact carry discourse as part of their own lifeblood", Guacira Lopes Louro proposes a scrutinizing look at the discursive processes and practices that lead certain body features to be seen as defining gender and sexuality and end up by defining subjects themselves (80). ${ }^{10}$

Valmiki's Daughter represents and underscores the diversity of lives of many individuals situated inside a region that has been perceived as primarily heterosexual, a perception deconstructed-queered-in Mootoo's novel. However, given the ways the destinies of the two main characters play out, Mootoo implicitly acknowledges the constricted space for individuals that do not abide by compulsory heterosexuality. The fact that Valmiki and Viveka have only two viable options, to leave the country or to live "a lie", attests the power of discursive processes and practices that still regulate bodies, genders and desires.

\section{Notes}

1. In Tourism and HIV/AIDS in Jamaica and The Bahamas, Ian Boxill examines the link between the spread of the HIV virus and sex tourism on the islands, claiming that "the tourist industry is founded on the idea of providing a place free from normal social constraints, a relaxed, often times hedonistic atmosphere, where consequences do not exist. For the tourist, it serves to satisfy those desires that are 'forbidden fruit' at home" (23).

2. At least thirteen of the Caribbean Community's ("CARICOM") fifteen states continue to criminalize samesex conduct under anti-sodomy statutes, and the region shows particular resistance to any foreign suggestions to repeal these laws. In addition to clinging to its homophobic laws, the Caribbean continues to resist any social or cultural human rights advocacy (Holness 928).

3. See Makeda Silvera's comments (1992) on the matter: "To be male was to be the stud, the procreator; to be female was to be fecund, and one's femininity was measured by the ability to attract and hold a man, and to bear children. In this way, slavery and the post-emancipated colonial order defined the structures of patriarchy and heterosexuality as necessary for social mobility and acceptance" (352).

4. In the last decades of the twentieth century a prominent group of Caribbean writers living in diaspora have engaged in discussions of gender, nationality, ethnicity and sexuality. Audre Lorde, Achy Obejas, Dionne Brand, Makeda Silvera, Michelle Cliff, Shani Mootoo, and other female writers, were able to break with previously established normative constructions of sexuality.

5. Hindu immigration to the Caribbean, and specifically to Trinidad and Tobago, started in the middle of the nineteenth century when land owners, faced with the end of slavery, resorted to cheap labor from East Indies workers that tended to cane and cocoa fields. Between 1854 and 1917, "India contributed approximately 134,183 indentured labourers to Trinidad and Tobago" (The Indian Diaspora 203). After their contracts expired, many remained on the island since land owners, not wanting to lose their workers, offered a piece of land to the ones that decided to keep working on the fields. Slowly, these previously indentured workers managed to buy more and more land and acquire big estates. Thus, "the Indian Diaspora in Trinidad began to scale the daunting economic heights of their new country and, in time, it became a viable economic force" (204).

6. Through Nayan's account, Mootoo suggests that the lives of Trinidadians in Canada are not as care-free as it may seem; racial prejudice harms third world citizens, even if those citizens are heterosexual and upper class. It is also 
ironic that Nayan improves his status, both in Canada and in Trinidad, by marrying a beautiful woman.

7. Linden Lewis addresses issues about women in sports and suggests that "hegemonic notions of the feminine conspire to suppress the masculine in women because of similar fears of being viewed as too aggressive, unladylike, masculine or lesbian. Here again, the spectre of homosexuality looms large" (6).

8. The notions of expediency and convenience contained in Trevor's words characterize the main heterosexual relationships in the novel.

9. According to O'Callaghan, “The forest is where Valmiki is allowed cross-class homosocial bonding with other men who like hunting, and where he allows himself to act on his desires for the beautiful Saul. The forest is the site where Viveka crosses the threshold of respectability and becomes physically intimate with Anick" (247).

10. The Butler quotes in Louro's chapter come from an interview to Prins and Meijer. See works cited.

\section{References}

Boxill, Ian et al. Tourism and HIV/AIDS in Jamaica and The Bahamas. Jamaica: Arawak Publications, 2005.

Butler, Judith. Gender Trouble. New York and London: Routledge, 2006.

Undoing Gender. New York: Routledge, 2004

Dolares de Arena. Direção: Laura Amelia Guzmán; Israel Cárdenas. Aurora Dominicana, 2014.

Donnel, Alison. "Caribbean Queer: New Meeting of Places and the Possible in Shani Mootoo's Valmiki's Daughter". Contemporary Women's Writing, Oxford, v. 6, n.3, (Nov. 2012): 213-232.

Twentieth-Century Caribbean Literature: Critical Moments in Anglophone Literary History. London and New York: Routledge, 2006.

Foucault, Michel. The History of Sexuality: Volume1: An introduction. New York: Vintage Books, 1990.

Gibbings, Wesley. Trinidad and Tobago-Health: The High Cost of Sex Tourism. 1997. Disponível em: <http:// www.ipsnews.net/1997/03/trinidad-and-tobago-health-the-high-cost-of-sex-tourism/>. Acesso em: 5 jan. 2015.

Glave, Thomas. Our Caribbean: A Gathering of Lesbian and Gay Writing from the Antilles. Durham and London: Duke University Press, 2008.

Helff, Sissy; Dalal, Sanghamitra. "The Quest for an Identity in Shani Mootoo's Valmiki's Daughter”. Rocky Mountain Review, special number. (2012a): 73-84.
Holness, Toni. "Lesbian, Gay, Bisexual, Trans, and Intersex Rights in the Caribbean: Using Regional Bodies to Advance Culturally Charged Human Rights". Brooklyn Journal of International Law, v. 38, n. 3, (2013): 926-957.

The indian diaspora. "Presents the history of Indian immigration”. Disponível em: <http://indiandiaspora.nic.in/ diasporapdf/chapter16.pdf>. Acesso em: 10 jan. 2015.

Lewis, Linden. "Man talk, Masculinity, and a Changing Social Environment". Caribbean Review of Gender Studies, v. 1, (2007): 1-20.

Louro, Guacira Lopes. Um corpo estranho: ensaios sobre sexualidade e teoria queer. São Paulo: Autêntica Editora, 2004.

Mannur, Anita."Postcript: Cyberscapes and the Interfacing of Diasporas." Braziel, Jana and Anita Mannur eds. Theorizing Diaspora. Malden: Blackwell Publishing, 2003. 283-290.

Mootoo, Shani. Valmiki's Daughter. Toronto: House of Anansi Press Inc., 2008.

O’Callaghan, Evelyn. "Sex, Secrets, and Shani Mootoo's Queer Families". Contemporary Women's Writing, Oxford, v. 6, n. 3. (Nov. 2012): 233-250.

Prins, Baukje; Meijer, Irene. "Como os corpos se tornam matéria: entrevista com Judith Butler." Trad. Susana Bornéo Funck. Revista Estudos Feministas. v. 10 (1), (2002): 155-167.

Rampaul, Gisele. "An interview with Shani Mootoo". STAN Magazine. (Apr./July 2011): 20-26.

Rich, Adrienne. "Compulsory Heterosexuality and Lesbian Existence”. Jackson, Steve; Scott, Sue (Ed.). Feminism and Sexuality: A Reader. New York: Columbia University Press, 1996. 130-143.

Silvera, Makeda. "Man Royal and Sodomites: Some Thoughts on the Invisibility of Afro-Caribbean Lesbians". Glave, Thomas (Ed.). Our Caribbean: A Gathering of Lesbian and Gay Writing from the Antilles. Durham and London: Duke University Press, 2008. 344-354.

Skeete, Geraldine. "Representations of Homophobic Violence in Anglophone Caribbean Literature”. Caribbean Review of Gender Studies, v. 4. (2010): 1-20.

Recebido em: 04/06/2015 Aceito em: 13/07/2015 